\title{
Marine and anthropogenic controls on the estuary of the Suriname River over the past 50 years
}

\section{K. Gersie ${ }^{1, *}$, P.G.E.F. Augustinus ${ }^{2}$ \& R.T. Van Balen ${ }^{3}$}

\author{
1 Department of Geology and Mining, Anton de Kom University of Suriname, Leysweg 86, Paramaribo, Suriname \\ 2 Utrecht University, Utrecht, The Netherlands \\ 3 Department of Earth Sciences, Vrije Universiteit Amsterdam, De Boelelaan 1085, 1081 HV Amsterdam, The Netherlands \\ * Corresponding author. Email: kathleen.gersie@uvs.edu
}

Manuscript received: 02 February 2016, accepted: 11 May 2016

\section{Abstract}

Humans have played an important role in fluvial systems because of the impact of their land-use activities, frequently leading to degradation of environmental conditions. Rivers, which are the primary agents in sediment transport, have thus been subject to changes in sediment fluxes. The Suriname River has been affected by anthropogenic activities since colonial times, and has experienced strong discharge and sediment-load changes since the construction of the Afobaka Dam in 1964. The river's estuary sediments largely consist of fine-grained sediments, originating, ultimately, from the Amazon River and transported by the strong tidal current. The influence of this tidal current is diminished at the head of the estuary, allowing the river flow to become dominant. Also remarkable is the interaction of the Suriname River and the westward-migrating mudbanks which is evident in the changing magnitude and volume of Braamspunt, a mudcape located at the mouth of the estuary. The regulated discharge of the river results in a change of the river's morphology, resulting, among other things, in the growth of river bars.

\section{Introduction}

Land-use activities, like converting natural landscapes for human use, have transformed a large proportion of the Earth's land surface. Although land-use activities vary greatly across the world, the ultimate outcome is generally the same: obtaining natural resources for human needs or purposes frequently causes degradation of environmental conditions (Foley et al., 2005). Fluvial systems play a key role in human impacts on the global system because rivers are the primary agents of transport of sediments from the land to the coasts and oceans. Changes in fluxes of sediments have been inferred in almost every catchment that has been converted for land use. For example, numerous studies have shown that fluxes to oceans have been reduced in catchments where reservoirs have been constructed (Wasson, 1996). However, while considerable research has been done on northern mid-latitude fluvial systems, much less attention has been paid to the human impact on tropical river systems. The objective of this study is to analyse the hydrologic and geomorphic evolution of the lower Suriname River, especially its estuary, in response to marine and anthropogenic controls during the last 50 years.

Suriname is located in the tropics of northern South America and has two rainy and two dry seasons each year. The country is drained by four large rivers, the Marowijne, Suriname, Coppename and Courentyne (Fig. 1). These rivers have a south to north orientation, and flow from the crystalline Precambrian Guyana Highlands via the unconsolidated sedimentary deposits of the coastal plain to the Atlantic 0cean. The two largest rivers in Suriname, the Marowijne and the Courantyne, run straight into the ocean without deflection (Rine, 1980). The mouths of the Suriname and Coppename rivers have westward orientations, which is common for the Guiana coast. The westward deflection is the result of lateral growth of the eastern, outer bank of the rivers. The Marowijne and Courentyne are not deflected because of the large discharge, especially in the rainy seasons. In such periods the river mouth is flushed.

The smaller main rivers, the Cottica, Commewijne, Saramacca and Nickerie fluvial systems, do not flow straight into the ocean. They deflect westward in their lower, coastal reaches, 


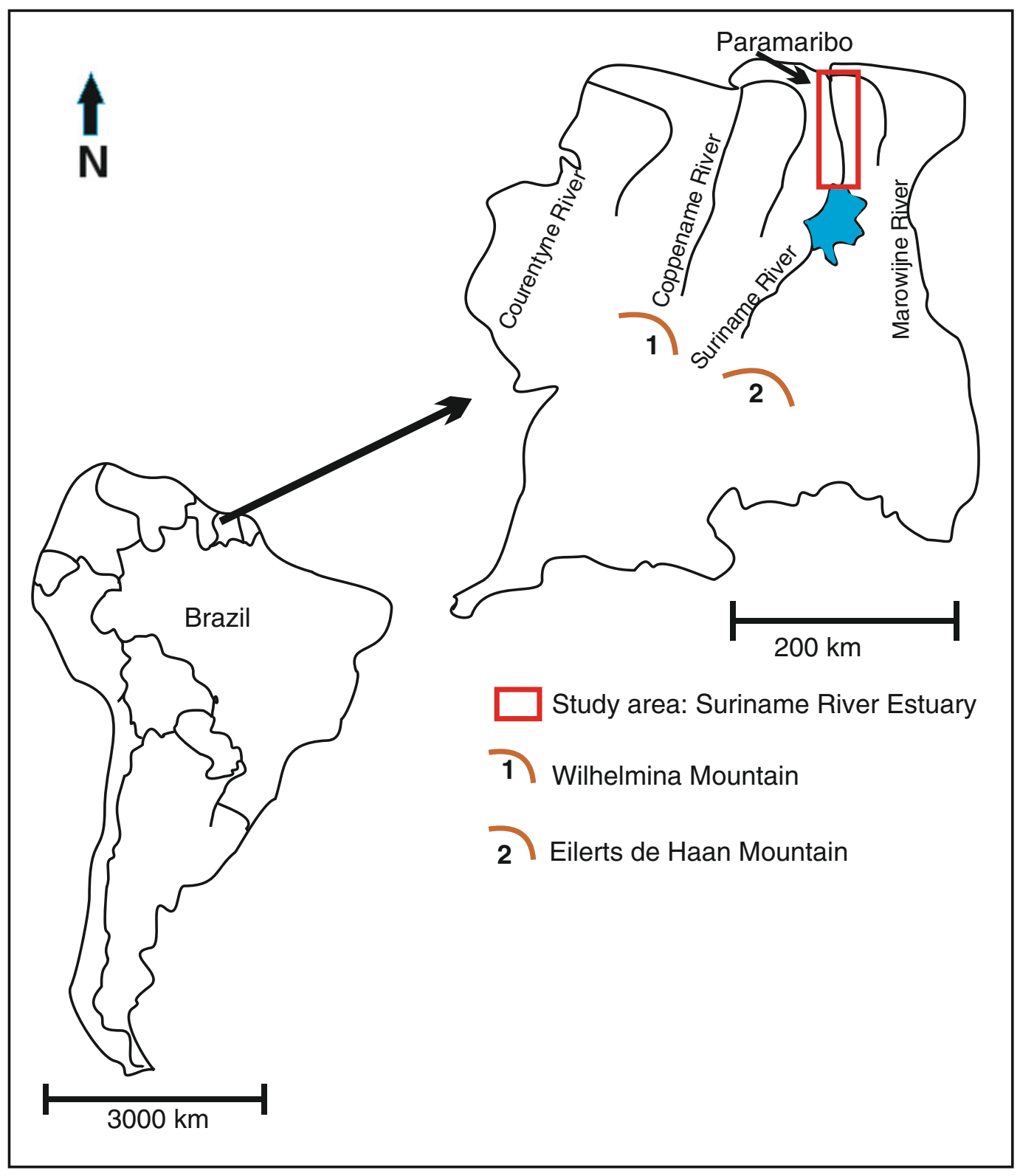

Fig. 1. South America with Suriname, its four main rivers and the study area (red rectangle: Suriname River estuary).

where they confluence with one of the large rivers. Augustinus (1978) attributes this westward deflection to the coincidence of relatively small river discharges and the westward migration of coastal mudbanks, when these cross the related river mouths.

This study focuses on the Suriname River, from an economic point of view the most important river in Suriname. It has been controlled by anthropogenic activities since colonial times (after 1900) when plantations were cultivated and fortresses were founded. Because of the river's importance and the resulting need to understand its behaviour, many measurement data have been collected in the past in its lower course and in the estuarine part.

This study is based on field observations and measurements described in the literature, supplemented with interpretations of aerial photographs and satellite imagery. Internal reports of the Maritime Authority Suriname (MAS) are also used, including depth measurements along channel cross-sections.

\section{Setting}

The Suriname River is $480 \mathrm{~km}$ long, and has its sources between the Wilhelmina Mountain and the Eilerts de Haan Mountain. The capital of Suriname, Paramaribo, is located on the left bank of the Suriname River estuary (Fig. 2). In 2009, to stop erosion processes, the government began constructing a dyke along the east bank of the estuary, dyke over c. $2 \mathrm{~km}$, from Jachtlust to Nieuw Amsterdam. 


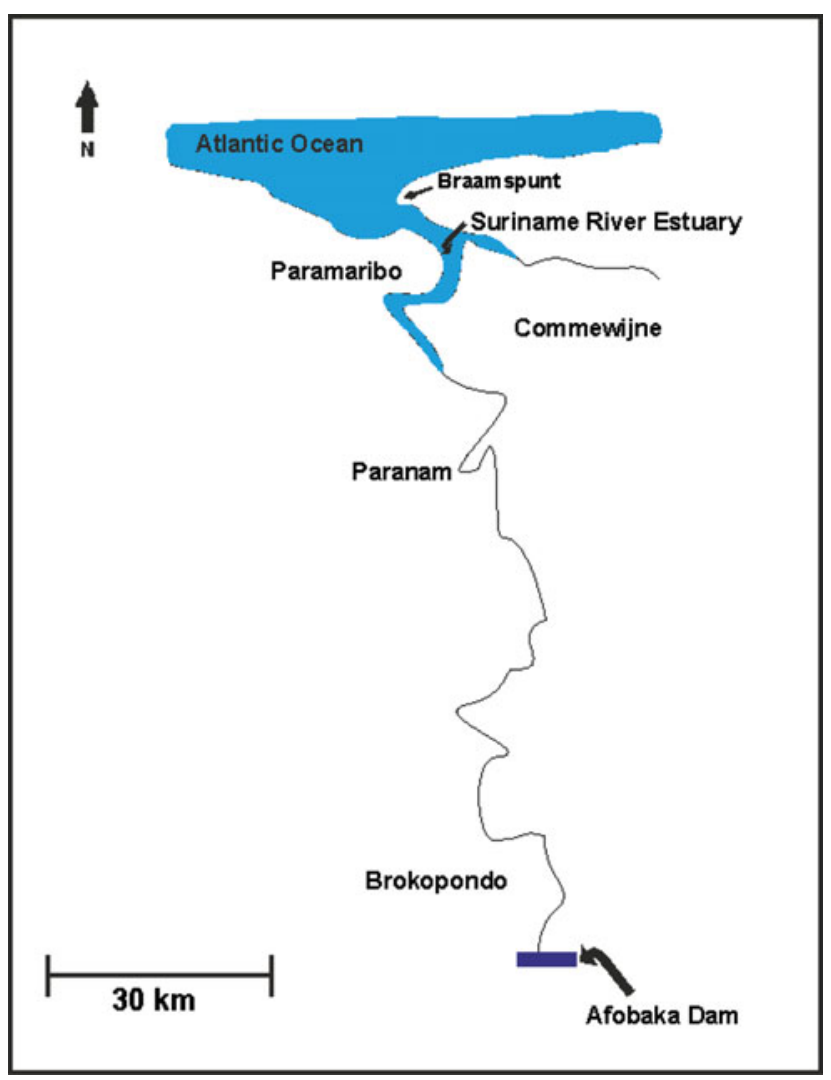

Fig. 2. The Suriname River estuary with the Braamspunt mudcape at the river mouth.

The Suriname River has an estimated average annual discharge of $440 \mathrm{~m}^{3} \mathrm{~s}^{-1}$ and an average annual sediment load of $0.25 \times 10^{6} \mathrm{t} \mathrm{a}^{-1}$ (Nedeco, 1968). Discharge and sediment load are strongly affected by the Afobaka Dam, located in the northern part of the shield region of the Suriname River basin (Fig. 2). This dam was constructed between 1961 and 1964, and started to operate in 1965 to provide electricity for the processing of bauxite and for domestic use in Paramaribo. Construction of the dam has diminished and regulated the downstream discharge. In addition, the artificial lake is a trap for coarser sediments (sand) supplied from upstream, and, as a result, the downstream riverbed is probably eroded. Sand currently dredged from the river bottom near Paranam, a small town downstream of the dam (Fig. 2), must have been deposited before the hydroelectric plant came into operation (Nedeco, 1968).

Downstream of Paranam, the clay content of the riverbed sediments increases in the seaward direction. The (slightly) sandy clays in the estuary (Fig. 2) contain only a small percentage of sand which, according to the mineralogical composition, originates from the nearby beach sand. It contains, however, a relatively high percentage of zircon, which points to an influence of the upstream Suriname River (Krook, 1979), before the construction of the Afobaka Dam. The beach sand both east and west of the Suriname River mouth originates from the Marowijne and Mana rivers (Augustinus, 1978), and its heavy mineral association differs from that of the Suriname River (Krook, 1979). However, the fine-grained sediments in the estuary ultimately originate from the Amazon River. They are transported by tidal currents into the estuary. The estimated amount is c. $250,000 \mathrm{ta}^{-1}$, based on an average sediment concentration of $20 \mathrm{~g} \mathrm{~m}^{-3}$ (Nedeco, 1968; SRK Consultants, 2008).

On both sides of the river, former coastlines can be recognised. They are marked by cheniers, which consist of sand and shells (or shell fragments). As previously mentioned, the sand originates from the Marowijne River, and is characterised by a heavy mineral association dominated by staurolite (Kiel, 1955; Augustinus, 1978; Krook, 1979). Shells are of (deep) marine origin and are, due to their form and low density, more easily transported than quartz sand (Augustinus, 1978). Sand and shells of the current spit at Braamspunt (Fig. 2) are from the same sources.

\section{Interaction of the coastal zone and estuary}

The coastal waters in front of the $364 \mathrm{~km}$ long coast of Suriname are mainly characterised by the Guiana current, which is a continuation of the South Equatorial Current. However, due to its low velocity, the Guiana current is not very important for the Suriname River estuary. Current velocities in the shallow coastal waters along the coast of Suriname are just high enough to enable the transport of silt and (very) fine sand (Nedeco, 1968; Augustinus, 1978).

In the near-coastal area, natural waves are very important for coastal development. In the estuary, however, they quickly lose energy due to refraction in response to shoaling towards the banks. Ship-induced waves, however, can play an important role in riverbank erosion (Van Heuvel, 1983).

\section{The tidal system in the estuary and its related morphology}

The tide along the coast of Suriname is semi-diurnal. The average tidal range is $1.80 \mathrm{~m}$. It can be classified as mesotidal since the mean wave height at spring tide is $2.80 \mathrm{~m}$; at neap tide it is $1.00 \mathrm{~m}$ (Nedeco, 1968).

The tidal wave approaches the Suriname coast from an almost perpendicular (NNW-N) direction. The sea water flows with rising tide via a shallow flood channel into and along the east side of the estuary (Fig. 3). Under these conditions, flow velocities of c. $1 \mathrm{~m} \mathrm{~s}^{-1}$ were observed by Van Heuvel (1983). In the westerly-situated fairway, the maximum flow velocity was $0.85 \mathrm{~m} \mathrm{~s}^{-1}$.

The incoming floodwater tends to flow as straight as possible. Near Resolutie, upstream, flow velocities of over $1 \mathrm{~m} \mathrm{~s}^{-1}$ 


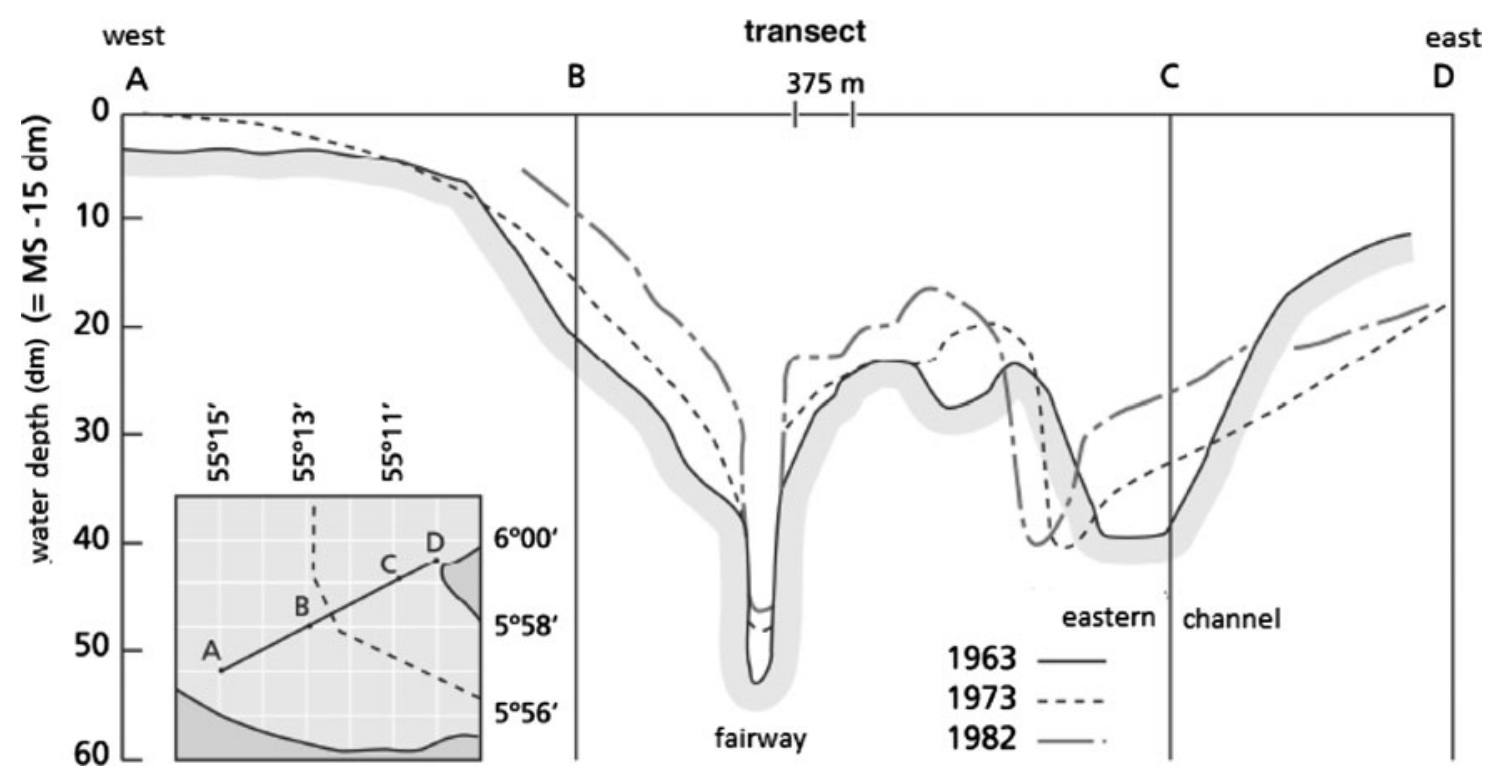

Fig. 3. Cross-section through the Suriname River estuary, showing the position of the fairway and, further east, a flood channel, over the years 1963,1973 and 1982 (after Van Heuvel, 1983).

were measured. Further upstream the flood channel ceases to exist. In the narrow flow profile between Leonsberg and Voorburg, only one channel is visible (Fig. 3). Flow velocities in this channel are up to $1.5 \mathrm{~m} \mathrm{~s}^{-1}$ (Van Heuvel,1983; Sunecon Consultants, 2004).

During ebb tide the deep westerly channel, the fairway, now functions as an ebb channel with flow velocities of c. $1 \mathrm{~m} \mathrm{~s}^{-1}$ (Van Heuvel, 1983; Sunecon Consultants, 2004).

There is a lack of flow velocity and discharge data for the tributary, the Commewijne River. Nevertheless, from the colour difference of the outflowing water near the confluence it can be inferred that during ebb tide the discharge of the Suriname River is much larger than that of the Commewijne River, despite the effects of the Afobaka Dam (Van Heuvel, 1983).

In the narrow passage between Leonsberg and Voorburg (Fig. 4) the outflowing fresh river water and in- and outflowing salty tidal water concentrate in the outer bend.

Cross-sections of the Suriname River, between Geyersvlijt and Jagtlust, show depressions with depths up to $40 \mathrm{~cm}$ (Fig. 5) near the east bank of the river (Commewijne), reaching a maximum in 1981. They probably function as flood channels.

Silt bars (Resolutie, Jagtlust, Dijkveld) are almost aligned with the current flow (Fig. 6), and in front of the river mouth a mouth bar, known as the Outer bar, is present. Therefore, according to the morphological classification of Dalrymple et al. (1992), the mesotidal Suriname River estuary can be classified as tide-dominated, although tide-dominated estuaries are more likely to occur in macrotidal areas. This is due to the strong flood tidal currents compared to the relatively small effects of the incoming waves. The tidal influence is diminished at the head of the estuary, allowing the river flow to become dominant (Dyer, 1997).

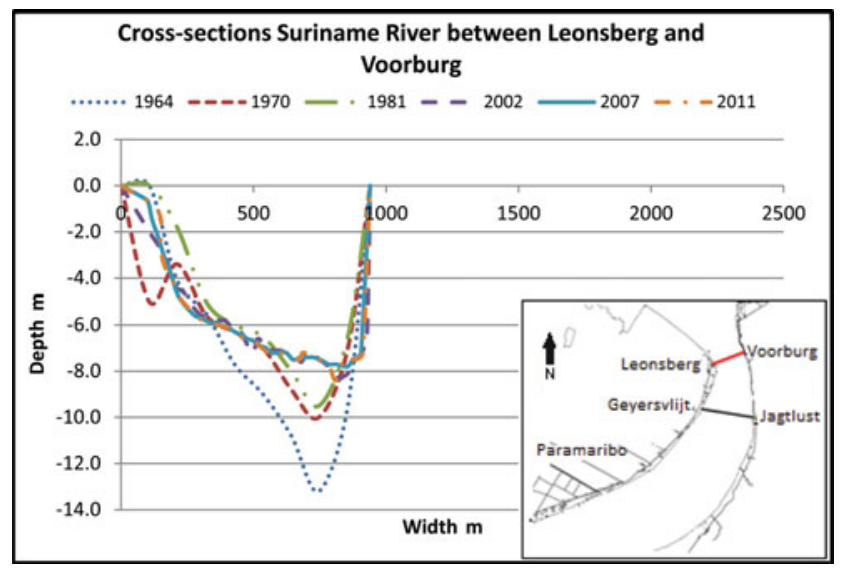

Fig. 4. Cross-section of the Suriname River estuary between Leonsberg and Voorburg.

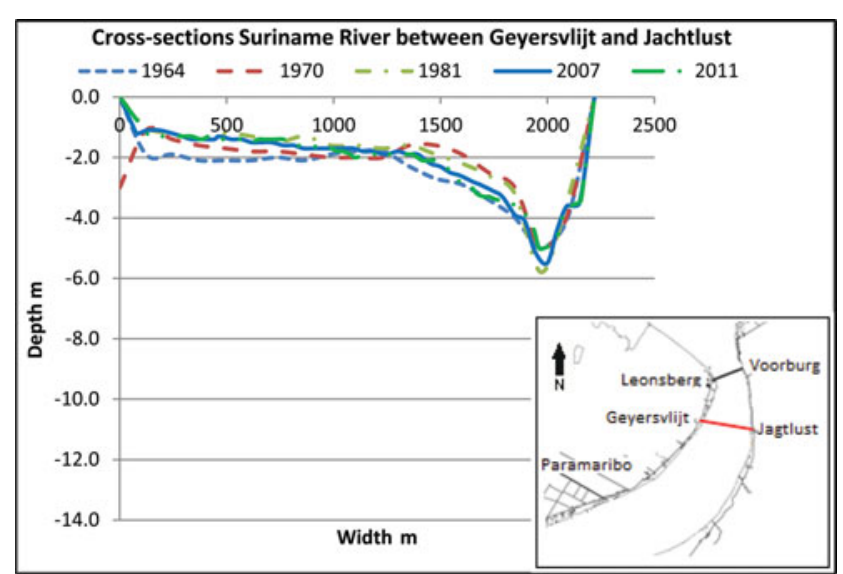

Fig. 5. Cross-section of the Suriname River estuary between Geyersvlijt and Jagtlust. 


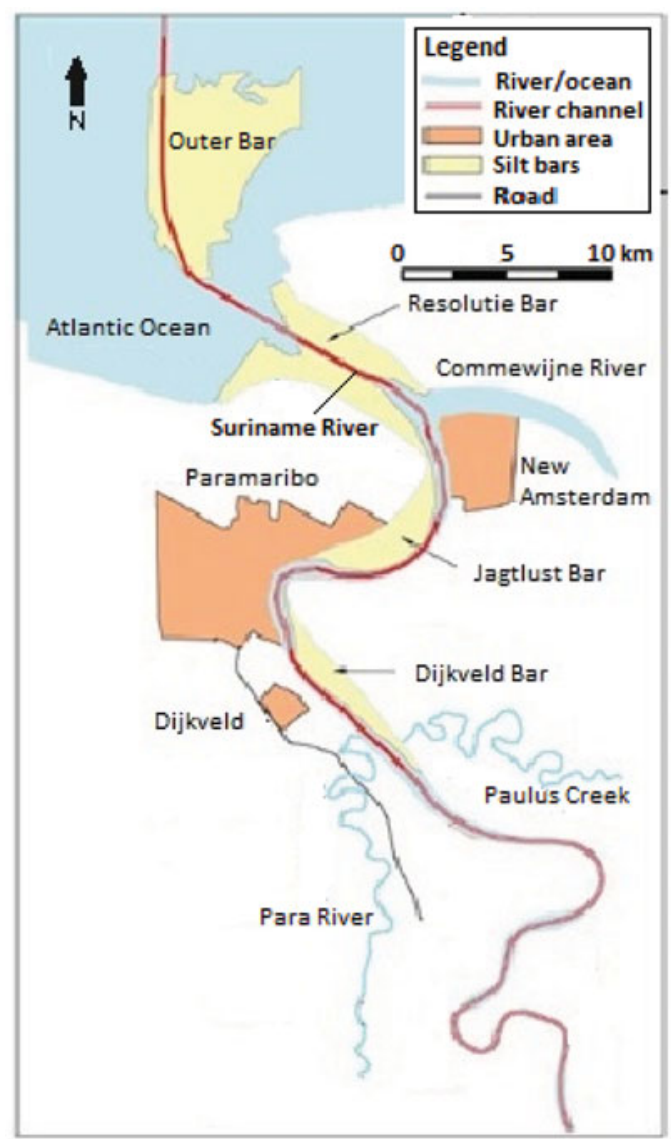

Fig. 6. Bars in the Suriname River (modified after SRK Consultants, 2008).

The bars are the result of the influx of silt from the Atlantic Ocean into the estuary and are especially prevalent along the riverbanks because the fairway is fixed with the aid of beacons. The silt ultimately originates from the Amazon River. The contribution from the upstream interior is estimated to be in the order of $2 \%$ (Nedeco, 1968). The Old and Young Coastal Plain consist for the most part of marine-deposited clays. Land-based runoff from that area will contribute silt that is also of Amazon origin.

\section{Coastal mudbanks}

Coastal development in Suriname is determined by the continuously westward-migrating system of mudbanks and interbank areas. Mudbanks vary in length between 30 and $60 \mathrm{~km}$ (Wells \& Coleman, 1978). They extend offshore to about the $20 \mathrm{~m}$ isobaths (Nedeco, 1968). The migration of the mudbanks is the result of deposition at their west side and erosion at their east side. Deposition at the west (down-drift) side of the mudbanks mainly takes the form of fluid muds (sediment suspensions of 10-330 $\mathrm{gl}^{-1}$ ). The high silt content of the sea water, together with resuspended particles from the east (up-drift) side of the mudbanks, can cause over-concentration at the down-drift side, giving rise to fluid mud formation. A property of fluid mud is that waves propagating over it are attenuated and even damped completely (Delft Hydraulics Laboratory, 1962; Diephuis, 1966). This calm environment favours further sedimentation; coastal accretion can be very fast (up to $200 \mathrm{~m} \mathrm{a}^{-1}$; Boyé, 1962). With ongoing migration of the mudbanks, in the course of time the original fluid mud consolidates and becomes overgrown with mangroves, furthering dehydration of the young soil. As a result, at the east side of the mudbank, the soil has matured to a young clay, which can be eroded by wave action. Migration due to erosion of the east side and sedimentation at the west side mainly takes place during the short dry season (February-April) when the trade winds are strongest (Augustinus, 1978).

In the interbank areas there is no fluid mud. Here the coast is subject to wave attack and rapid erosion of the mangrove fringe (Augustinus, 1978; Plaziat et al., 1994). If sand or shell material is available in this erosive environment, small beach ridges, cheniers, are formed on the clayey subsoil, due to wave action (Russell \& Howe, 1935; Price, 1955). Cheniers run parallel with or at small angles to the common shoreline and characteristically cluster at one or both sides of a major river (Fig. 7). Along the eastern part of the Suriname coast, the chenier sand mainly originates from the Marowijne/Mana river system. Shells and shell fragments are the remains of molluscs and gastropods living in the coastal waters (Price, 1955).

In specific cases a chenier can grow seaward and form an extensive beach or spit. This occurs if a retreating coast cuts into an older chenier, which thenceforth acts as a local source of coarse sediment (Augustinus, 1978).

The migrating mudbanks are the driving force behind the development of the smallest coastal unit. Between the mudbanks interbank areas exist. Together the mudbanks and adjacent interbank areas form the smallest coastal unit (Augustinus, 2004).

Their migration velocity varies roughly between 0.5 and $1.5 \mathrm{~km} \mathrm{a}^{-1}$. The period of one cycle of coastal accretion (mudbank) and coastal erosion (interbank area) is 30-35 years.

The variation in the length of the mudbanks and in their migration velocity appears to be related to coastal development at a higher temporal (150-200 years) and spatial (100-150 km) scale. This large-scale coastal behaviour appears to be governed by a change in frequency of wind directions and wind force (Eisma et al., 1991; Augustinus, 1993, 2004). Analysis of wind data from Kourou (French Guiana) has demonstrated a steady change in wind directions from northeast to east, together with an increase in wind force over the period 1957-1986. Waves generated by these winds will approach the more or less eastwest-running coast under a smaller angle as compared to waves generated by northeasterly winds. This means that the alongshore component of the wave energy flux becomes stronger, favouring alongshore transport, and the cross-shore component becomes weaker, leading to a reduction in coastal erosion. As a result, mudbanks should grow longer, which indeed appears to be the case over the period 1947-2001 (Augustinus, 2004). In 


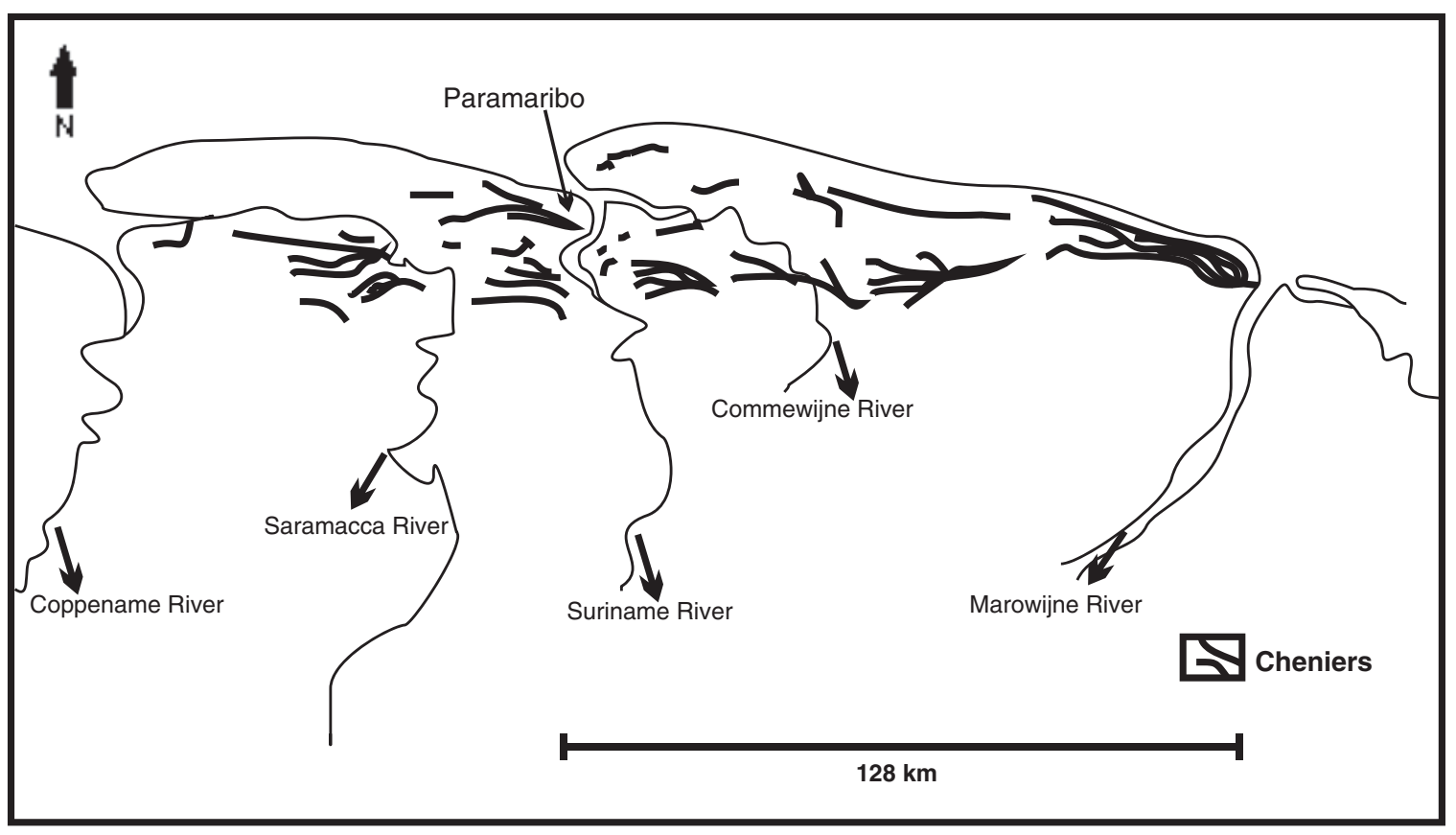

Fig. 7. Part of the coastal area of Suriname with east-west-oriented cheniers (black) (Zonneveld, 1968).

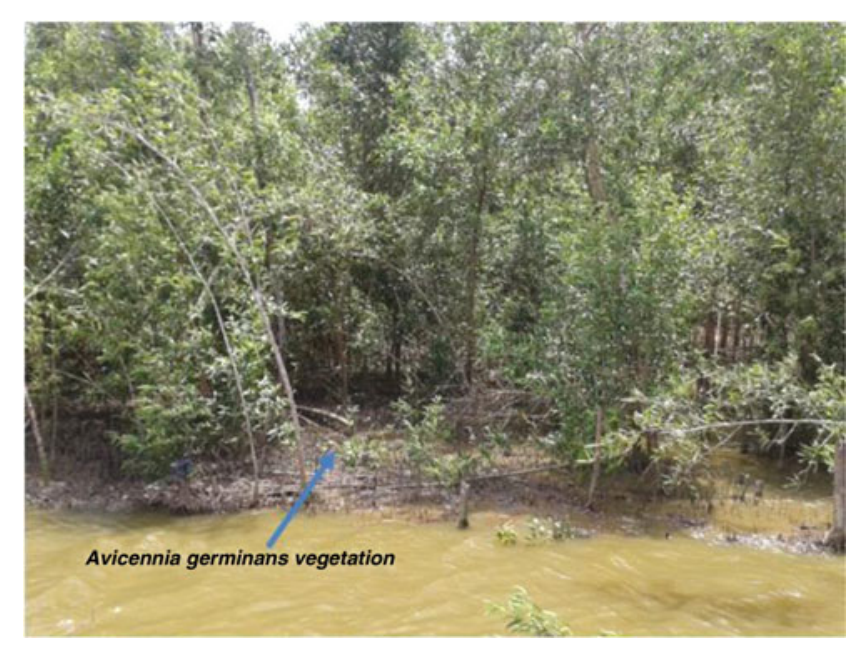

Fig. 8. Avicennia germinans marsh.

2001, the length of the mudbank east of the Suriname estuary was in the order of $70 \mathrm{~km}$.

After mudbanks are colonised by vegetation, they develop into brackish and salty Avicennia marshes (Fig. 8). Due to chenier formation, these are cut off from regularly flooding with sea water. If they subsequently become desalinised, they change into clay marshes with fresh forests or grass swamps. On top of the tidal clay flats, eustatic peat sometimes forms in swamps (Teunissen, 1978).

Mudbanks migrating westward in front of an estuary are situated at a certain distance from the coast. This feature was described by Delft Hydraulics Laboratory (1962) and attributed to the influence of the river discharge. This fits very well the new mudbank hypothesis of Allison and Lee (2004), that the mudbanks consist of two parts: a free migrating mudwave consisting of fluid mud (high-density suspended mud), and a second part consisting of deposited mud (formed out of suspended and of fluid mud). The second part is located at the landward side of the mudbank, in the lee of currents and waves, and is connected to the coast. In front of an estuary this connecting part will not come into being, due to the turbulence of the inand outflowing water.

\section{The Braamspunt mudcape}

The effect of alongshore-migrating mudbanks on the estuary is also expressed by the magnitude and volume of the Braamspunt mudcape on the east bank of the river mouth (Fig. 2). The cape exists due to east-west alongshore processes (e.g. mud supply and wind orientation), and extends when a mudbank is passing and the river discharge is too small to stop this development. The cape retreats in response to an interbank environment.

The influence of a westward-migrating mudbank on a downdrift estuary was studied by Allison et al. (2000) for the Cassipore mudcape in Brazil. This mudcape is subject to periodical mud supply due to seasonal and decadal cycles in trade wind energies. resulting in alternating periods of formation and starvation in the coastal zone.

The behaviour of Braamspunt in relation to coastal development can be inferred from historical maps, aerial photographs and satellite images (Figs 9 and 10). In the period 1947-1970 a mudbank migrated beyond Braamspunt, and the cape generally 


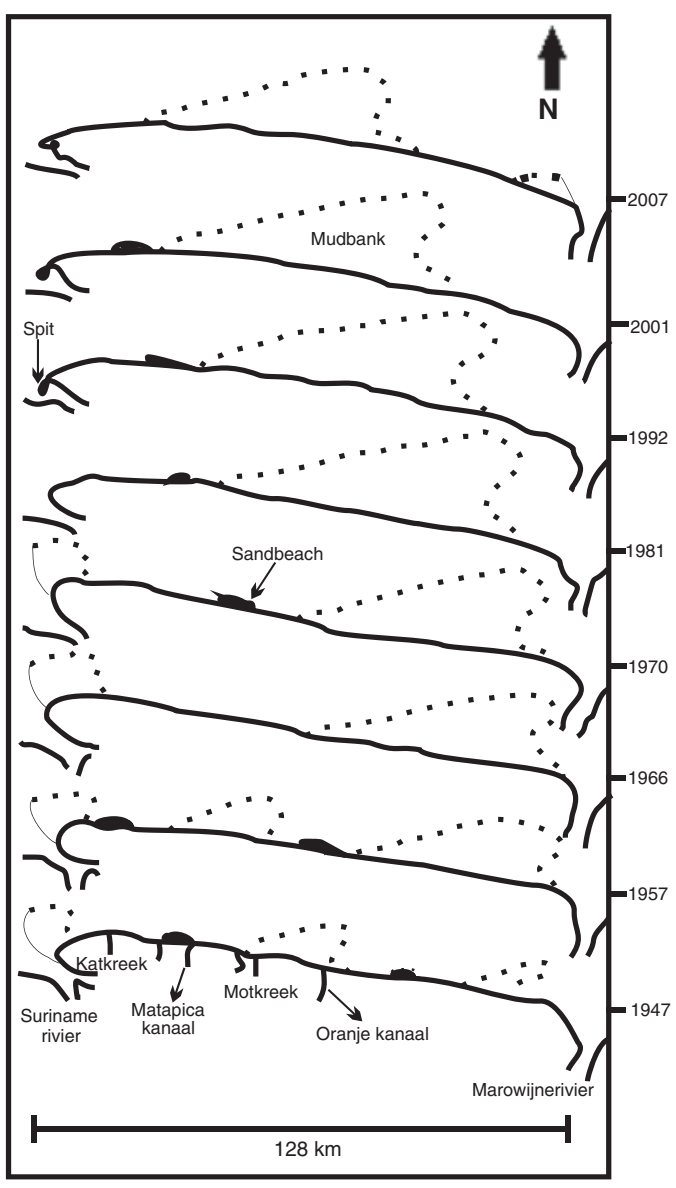

Fig. 9. Mudbank migration from 1947 to 2007 (modified after Zonneveld, 1953).

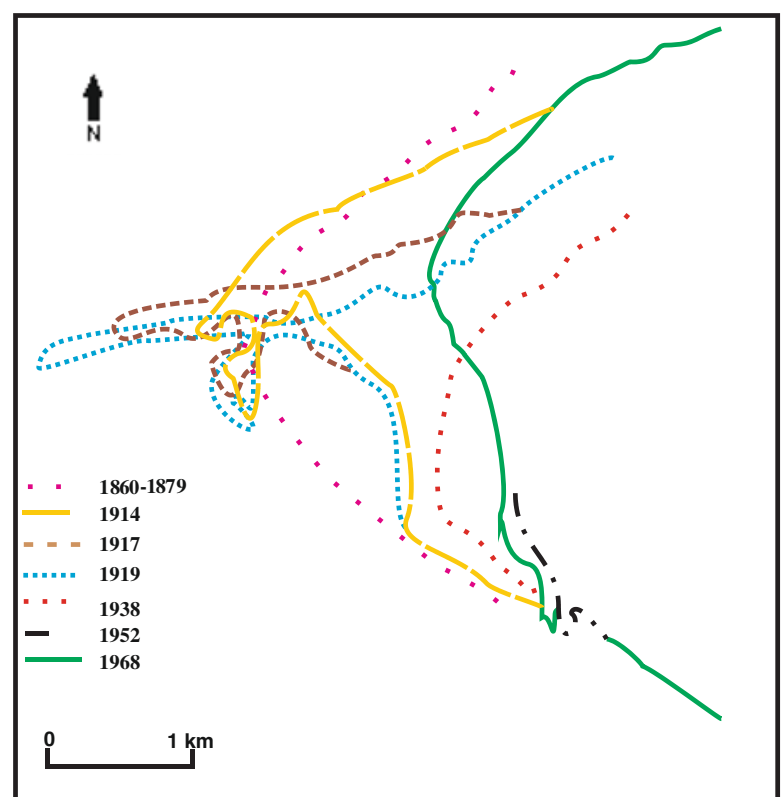

Fig. 10. Coastlines at Braamspunt from different years (1860-1968) (modified after Zonneveld, 1953). showed accretion. In the following years, coastal erosion dominated, resulting in coastal retreat. Episodically, Braamspunt is characterised by a sand spit. Evidently, this can only occur in an interbank environment. Zonneveld (1953) described the evolution of a sand spit at Braamspunt, based on recent surveying and topographic maps. From 1914 to 1930 a sand spit existed.

By 1938 it was no longer present (Fig. 10); part of the sand was transported across the estuary to form a new chenier northwest of Paramaribo, while another part was transported into the estuary to form a small sandy riverbank, south of the former spit (Fig. 10). Some 50-55 years later, during the 1980s, a new sand spit started to develop at Braamspunt; it is still present, so it appears that spit formation is not related to the 30 year cycle of coastal development in Suriname.

The formation of a spit requires a certain volume of sand. During normal longshore transport conditions, selection of the sediment takes place. Coarser and heavier grains are likely to stay behind, so the amount of sand in a chenier decreases and its mean grain size becomes finer in the westward direction (Augustinus, 1978). As a result, the relatively fine sand that finally reaches Braamspunt is too small in quantity for the formation of a sand spit.

If, however, due to severe coastal erosion, a chenier of a former coastline is eroded, a new sand source is tapped; in such cases large sandy beaches can develop. Augustinus (1978) indicates this situation as a 'sand accretionary coast'. At the mouth of creeks and rivers, and along protruding parts of the coast, accretionary cheniers develop as spits.

These accretionary cheniers and spits always develop in interbank areas, as can be deduced from Fig. 9. In 1947, two accretionary beaches were present. Until 1957, both migrated westward, in phase with the east and west adjoining mudbanks. In 1966, however, the more westerly of the two appears to be overtaken by the eastward adjoining mudbank. Not until the mid-1980s did this sand became available again to form a new spit at Braamspunt. This, at least partly, explains why spit formation at Braamspunt is an episodic feature (Fig. 11).

Actually, the spit at Braamspunt is in its final phase, which is accelerated by the extraction of sand at its east side for the purpose of construction in Paramaribo (Fig. 11). These sand extractions seem to decrease the volumes of sand at Braamspunt. From the east a new accretionary sand beach and an adjacent mudbank are approaching (Fig. 9). The question is which of these two, the spit or the mudbank, will arrive first at Braamspunt. In the latter case, the spit will be fixated for the coming decades before it will reach Braamspunt.

Looking at Fig. 9, it is striking that no new accretionary cheniers and spits formed after 1947. Apparently, ever since that time, erosion of the coast of East Suriname has not been severe enough to erode an older chenier along a former coastline. This is in tune with the increasing length of the mudbanks (Eisma et al., 1991; Augustinus, 2004), indicating the increase in coastal 


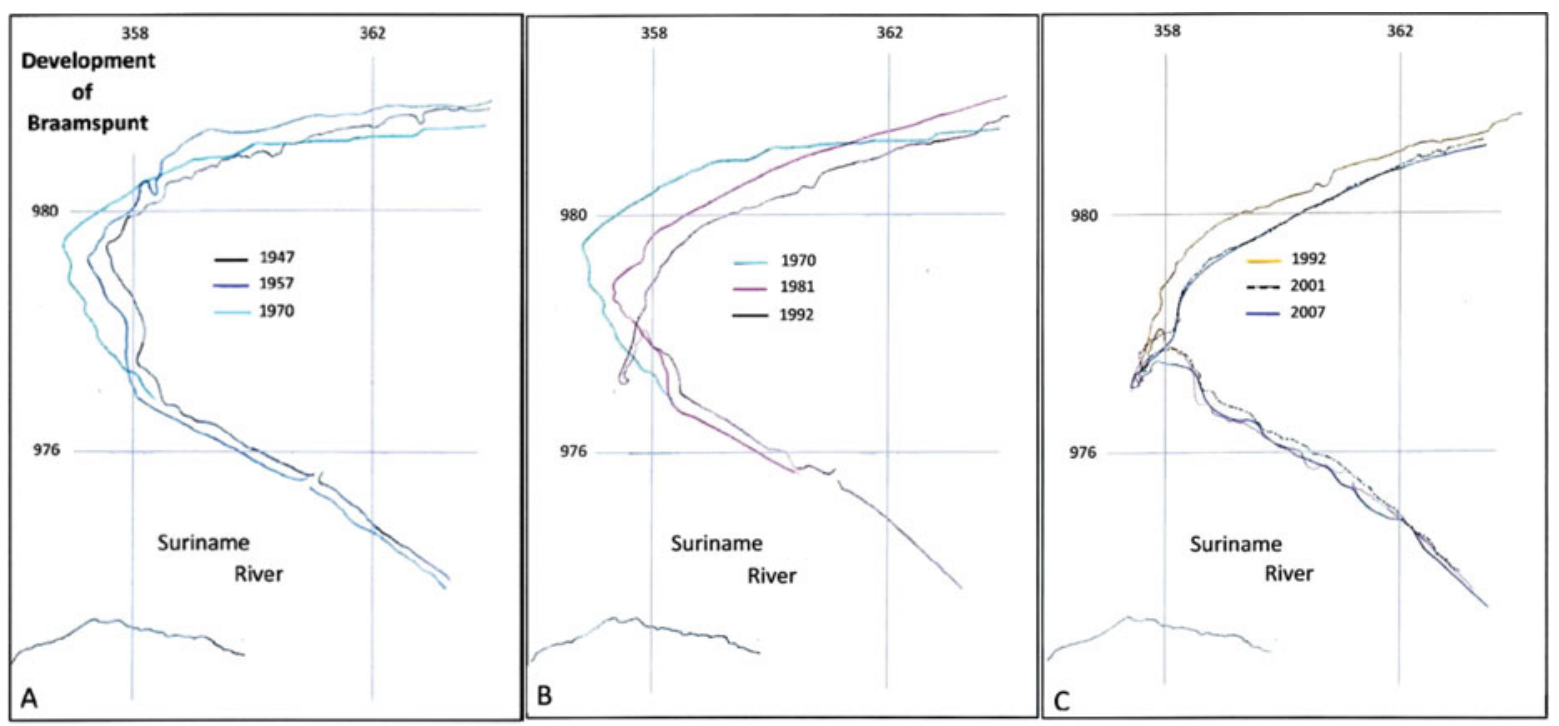

Fig. 11. The coastline of Braamspunt: (A) coastal accretion from 1947 to 1970; (B) coastal erosion and starting spit formation from 1970 to 1992; (C) coastal erosion and spit development from 1992 to 2007. Note: black arrows refer to sand extraction activities.

mud accretion. The phenomenon appears to be related to the (expected) phase of large-scale coastal behaviour in which (net) coastal retreat is predominant.

\section{Response to dam construction}

\section{Channel cross-section evolution}

The channel cross-section between Leonsberg and Voorburg (Fig. 4) shows that the fairway has silted up and has become shallower since 1964, corresponding to the construction of the Afobaka Dam. A few years after the construction, this process was demonstrated by Bles \& De Hartog (1968). The depth decreased from $13.2 \mathrm{~m}$ in 1964 to $10 \mathrm{~m}$ in $1970,9.5 \mathrm{~m}$ in 1981 , and $7.4 \mathrm{~m}$ in 2011 . Thus, approximately $4.8 \mathrm{~m}$ was silted up in 48 years. In the beginning, silting up was faster, about $3 \mathrm{~m}$ in 6 years, and lateral migration of the channel towards the outside bend stopped completely. After 1981, silting-up slowed to about $2 \mathrm{~m}$ in 31 years. From 1992 onwards, the channel shows a distinct migration towards the outside curve, as is the normal process in outside river bends. Sometime between 1981 and 1992 the response time appears to be over. As the fairway (channel) comes closer to the riverbank, the latter will be strongly undermined, resulting in steeper bank slopes. Losing stability, the bank finally collapses. Along the riverbank between Nieuw-Amsterdam and Jagtlust, several examples of this process were noticeable. Therefore, a dyke has recently been constructed to defend this area (Fig. 12).

As shown by the cross-section in Fig. 5, the channel between Geyersvlijt and Jagtlust silted up between 1964 (construction of the Afobaka Dam) and 1970. This can be ascribed to the response of the river to changes caused by the construction of the Afobaka hydroelectric dam. Thus, adaptation of the Suriname River channel to changes due to construction of the Afobaka Dam took at least 17 years. Although the channel depth decreased significantly between 1964 and 1970, by 1981 the channel became deeper, reaching a depth of 5.8 $\mathrm{m}$ (Fig. 5). This can be explained by the increase in number of deeply loaded ore ships passing the channel between 1960 and 1973, combined with their increase in size (till 1979). An indication of the development of the number and size of ships for the periods 1957-1981 and 1983-2015 is presented in Figs 13 and 14. Finally, in 2007 a depth of $5.5 \mathrm{~m}$ was measured, and in 2011 a depth of c. $5.0 \mathrm{~m}$.

\section{Conclusions}

Both coastal factors and dam construction appear to have led to significant changes in the estuary system. Significant impacts are the consequences of the construction of the Afobaka Dam: the reduced and regulated discharge of the Suriname River and the trapping of mainly coarse sediment behind the dam. The regulated discharge leads to major import of sediments from the coast, changing the rivers' morphology over the years and resulting in the growth of river bars (e.g. the Jagtlust Bar). Another result was that the estuary became more tidal-dominated.

From the cross-sections in Figs 4 and 5 it is apparent that the bedding of the Suriname River has silted up since the construction of the Afobaka Dam. The river channel adaptation to the change in discharge took at least 17 years; however, erosion processes in the outer bends never stopped.

The influence of the westward-migrating system of mudbanks and interbank areas is expressed by changes in the magnitude and volume of Braamspunt (Fig. 11). The episodic 


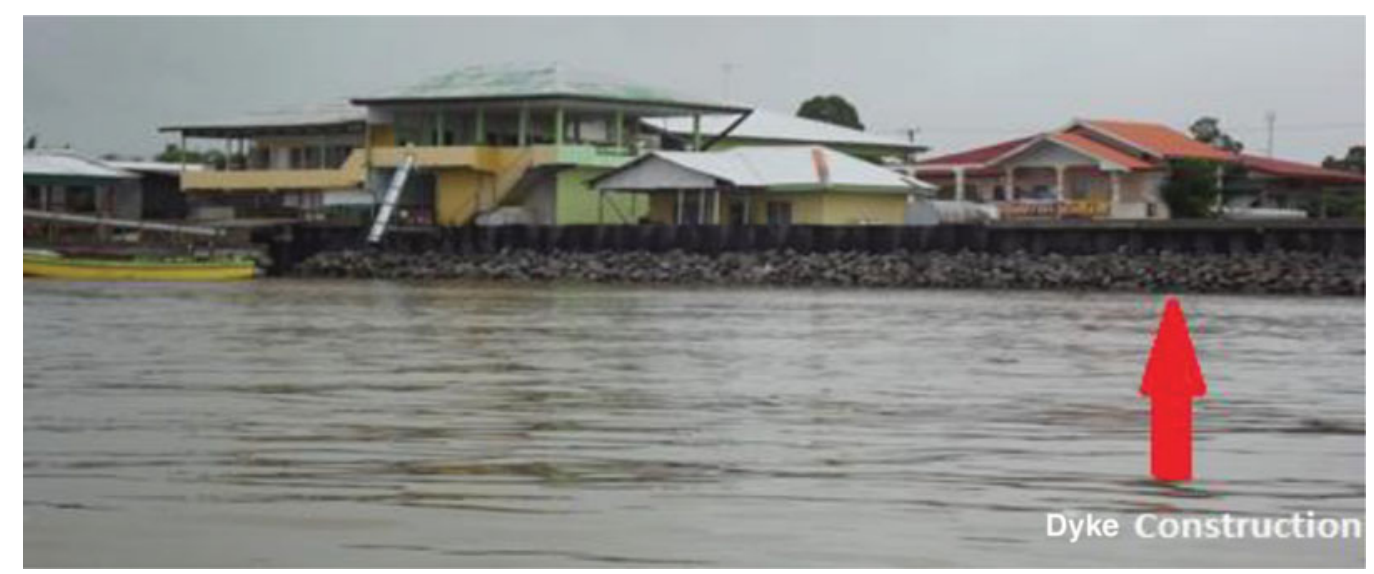

Fig. 12. Dyke construction along the right bank of the Suriname River.

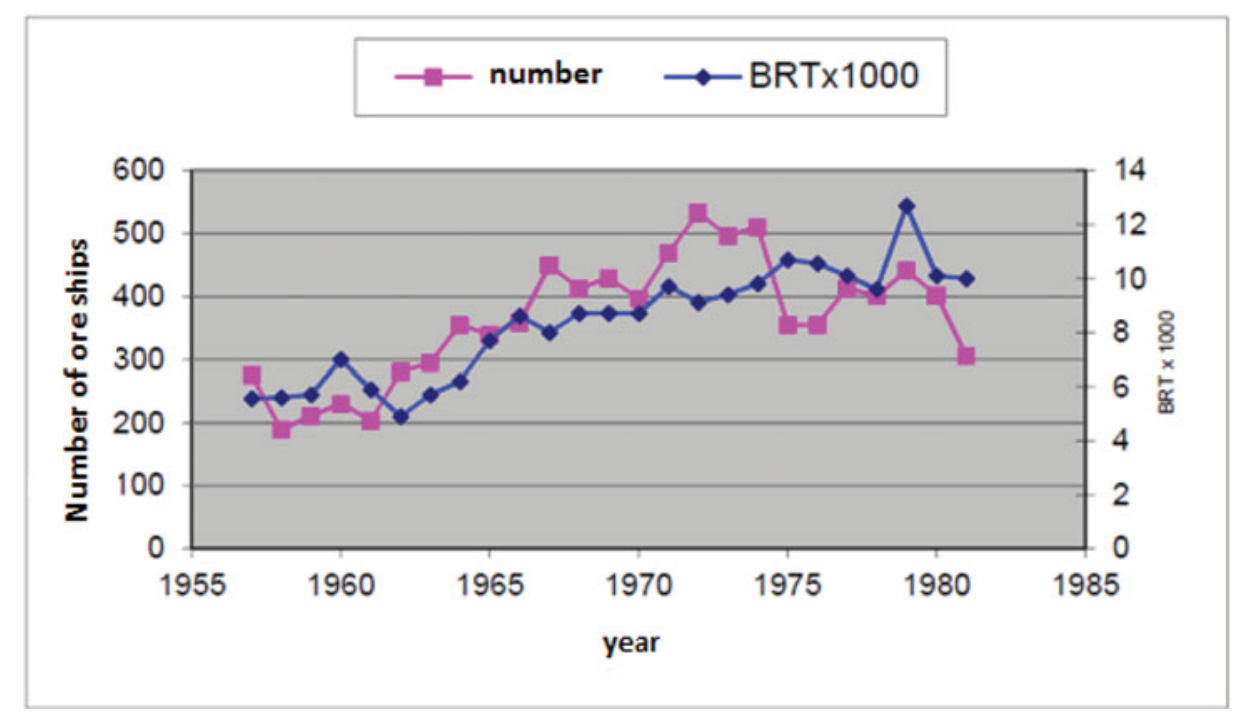

Fig. 13. Changes in the number and size of ore ships passing through the Suriname River (after Van Heuvel, 1983).

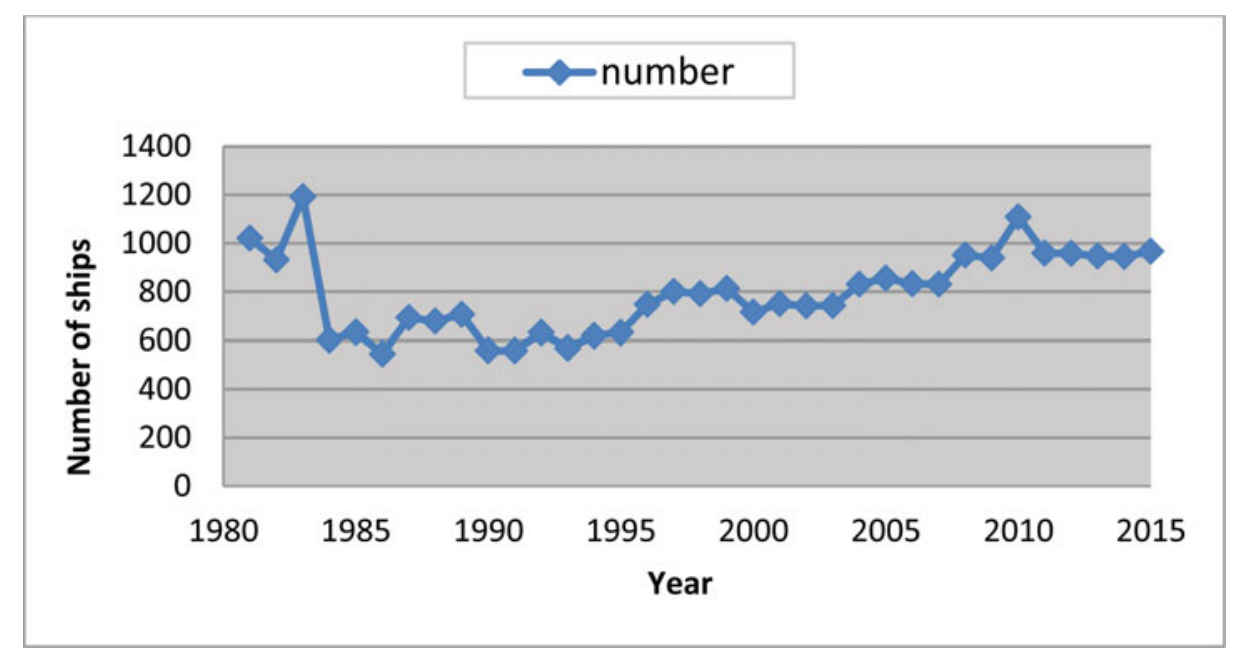

Fig. 14. Changes in the number of ships passing through the Suriname River (MAS, 2016). 
development of a sand spit at Braamspunt is related to the development of accretionary cheniers in periods of severe coastal erosion (within the cycle of large-scale coastal behaviour). When an accretionary chenier during its migration is overtaken by a mudbank that migrates with a higher velocity, it will be fixated for some 15-20 years, making the feature even more episodic.

The erosion and finally disappearance of the sand spit at Braamspunt is caused by a shortage of sand supply. This is usually due to an approaching mudbank which hampers sand transport. Erosion is accelerated by the local extraction of sand. It is recommended that monitoring activities be executed by local authorities in the future.

\section{Acknowledgements}

Professor Dr Hans Renssen is thanked for his support and views, Professor Theo Wong for his support, Mrs Bernice Mahabier, Ms Nancy Yang and Mr Lloyd Gemerts from the Maritime Authorities Suriname for their help and making data available.

\section{References}

Allison, M.A. \& Lee, M.T., 2004. Sediment exchange between Amazon mudbanks and shore-fringing mangroves in French Guiana. Marine Geology 208: 169190.

Allison, M.A., Lee, M.T., Ogston, A.S. \& Aller, R.C., 2000. Origin of Amazon mudbanks along the northeastern coast of South America. Marine Geology 163: 241256.

Augustinus, P.G.E.F., 1978. The changing shoreline of Surinam (South-America). PhD Thesis. Utrecht University: $232 \mathrm{pp}$. Also published as: Publications of the Foundation for Scientific Research in Surinam and the Netherlands Antilles, Utrecht, no. 95: $232 \mathrm{pp}$.

Augustinus, P.G.E.F., 1993. Coastal development in Suriname at different temporal and spatial scales. In: List, J.H. (ed.): Large scale coastal behavior '93. US Geological Survey 0pen File Report 93-381: 1-4.

Augustinus, P.G.E.F., 2004. The influence of the trade winds on the coastal development of the Guianas at various scale levels: a synthesis. In: Baltzer, F., Allison, M.A. and Fromard, F. (eds.): Material exchange between the upper continental shelf and mangrove-fringed coasts with special reference to the N. Amazon-Guianas coast. Marine Geology 208, Special Issue: 145-151.

Bles, A.M. \& De Hartog, A.H., 1968. Nota betreffende de verondieping van de benedenloop van de Suriname Rivier. Waterloopkundige Afdeling Paramaribo, P. 68-3: $5 \mathrm{pp}$.

Boyé, M., 1962. Les palétuviers du littoral de la Guyane française: ressources et problèmes d'exploitation. Les Cahiers d'Outre-Mer 15: 271-290.

Dalrymple, R.W., Zaitlin, B.A. \& Boyd, R., 1992. A conceptual model of estuarine sedimentation. Journal of Sedimentary Petrology 62: 1130-1146.

Delft Hydraulics Laboratory, 1962. Demerara Coastal Investigation. Report on siltation of Demerara bar channel and coastal erosion in British Guiana. Delft Hydraulics Laboratory (Delft): 240 pp.
Diephuis, J.G.H.R., 1966. The Guiana coast. Tijdschrift van het Koninklijk Nederlands Aardrijkskundig Genootschap 83: 145-152.

Dyer, K., 1997. Estuaries, a physical introduction, 2nd edn. John Wiley and Sons (Chichester): $195 \mathrm{pp}$.

Eisma, D., Augustinus, P.G.E.F. \& Alexander, C.A., 1991. Recent and sub recent changes in the dispersal of Amazon mud. Netherlands Journal of Sea Research 28: 181-192.

Foley, J.A., DeFries, R., Asner, G.P., Barford, C., Bonan, G., Carpenter, S.R., Chapin, F.S., Coe, M.T., Daily, G.C., Gibbs, H.K., Helkowski, J.H., Holloway, T., Howard, E.A., Kucharik, C.J., Monfreda, C., Patz, J.A., Prentice, I.C., Ramankutty, N. \& Snyder, P.K., 2005. Global consequences of land use. Science 309: 570-574.

Kiel, H., 1955. Heavy mineral investigations of samples of Suriname. Geology and Mining 17: 93-103.

Krook, L., 1979. Sediment petrographical studies in northern Suriname. PhD Thesis. Vrije Universiteit Amsterdam (Amsterdam): $154 \mathrm{pp}$.

Maritime Authority Suriname (MAS), 2016. Statistics concerning vessels navigating through the Suriname River. MAS (Paramaribo):1 p.

Nedeco, 1968. Surinam Transportation Study: a report on hydraulic investigation. Nedeco (The Hague): $293 \mathrm{pp}$.

Plaziat, J.C., Prost, T., Baltzer, F. \& Rudant, J.P., 1994. Specificities of exposed shoreline mangals in French Guiana. Abstracts of the 14th International Sedimentological Congress. Recife, Brazil: 69-70.

Price, W.A., 1955. Environment and formation of the chenier plain. Quaternaria 2: $75-86$.

Rine, J.M., 1980. Depositional environments and Holocene reconstruction of an argillaceous mud belt - Suriname, South America. PhD Thesis. University of Miami (Tallahassee): $222 \mathrm{pp}$.

Russell, R.J. and Howe, H.V., 1935. Cheniers of southwestern Louisiana. Geographical Review 25(3): 449-461.

SRK, Consultants, 2008. Sediments and geomorphology baseline study for Suriname River Dredging Project (SRDP). Maritime Authority Suriname (Paramaribo): 207 pp.

Sunecon, Consultants, 2004. Morfologische aspecten en natuurlijke oeverbescherming. Ministerie van Openbare Werken (Paramaribo): $45 \mathrm{pp}$.

Teunissen, P.A., 1978. Reconnaissance Map Surinam Lowland Ecosystems (Coastal Region and Savanna Belt), scale 1:200.000. Ed. STINASU/LBB (Paramaribo): $50 \mathrm{pp}$.

Van Heuvel, T., 1983. Studie naar het gedrag van slib in en rond het estuarium van de Suriname rivier, in verband met de bevaarbaarheid van de toegangsgeul vanuit zee naar Paramaribo. Afstudeerwerk Technische Hogeschool Delft, Nederland, vakgroep Kustwaterbouwkunde, Eindstudie: 123 pp. + Bijlagen.

Wasson, R.J., 1996. Land-use and climate impacts on fluvial systems during the period of agriculture. PAGES Workshop Report, Series 96-2: $51 \mathrm{pp}$.

Wells, J.T. \& Coleman, J.M., 1978. Longshore transport of mud by waves: northeastern coast of South-America. Geologie en Mijnbouw 57: 353-359.

Zonneveld, J.I.S., 1953. Kustveranderingen aan de mond van de Surinamerivier. Geologie en Mijnbouw 15: 251-254.

Zonneveld, J.I.S., 1968. The evolution of the coastal area of Surinam (South America). In: Morrison, R.B. \& Wright, H.E. (eds): Means of correlation of Quaternary successions. 17th Congress of the International Association for Quaternary Research. Conference proceedings 8. University of Utah Press (Salt Lake City): 577-589. 